\title{
THE
}

$10-2013$

\section{Feasibility of using low density polyethylene sheets to detect atmospheric organochlorine pesticides in Alexandria, Egypt}

Mohammed A. Khairy

Rainer Lohmann

University of Rhode Island, rlohmann@uri.edu

Follow this and additional works at: https://digitalcommons.uri.edu/gsofacpubs

The University of Rhode Island Faculty have made this article openly available.

Please let us know how Open Access to this research benefits you.

This is a pre-publication author manuscript of the final, published article.

Terms of Use

This article is made available under the terms and conditions applicable towards Open Access

Policy Articles, as set forth in our Terms of Use.

\section{Citation/Publisher Attribution}

Mohammed A. Khairy, Rainer Lohmann, Feasibility of using low density polyethylene sheets to detect atmospheric organochlorine pesticides in Alexandria, Egypt, Environmental Pollution, Volume 181, October 2013, Pages 151-158.

Available at: http://dx.doi.org/10.1016/j.envpol.2013.06.031.

This Article is brought to you for free and open access by the Graduate School of Oceanography at DigitalCommons@URI. It has been accepted for inclusion in Graduate School of Oceanography Faculty Publications by an authorized administrator of DigitalCommons@URI. For more information, please contact digitalcommons-group@uri.edu. 


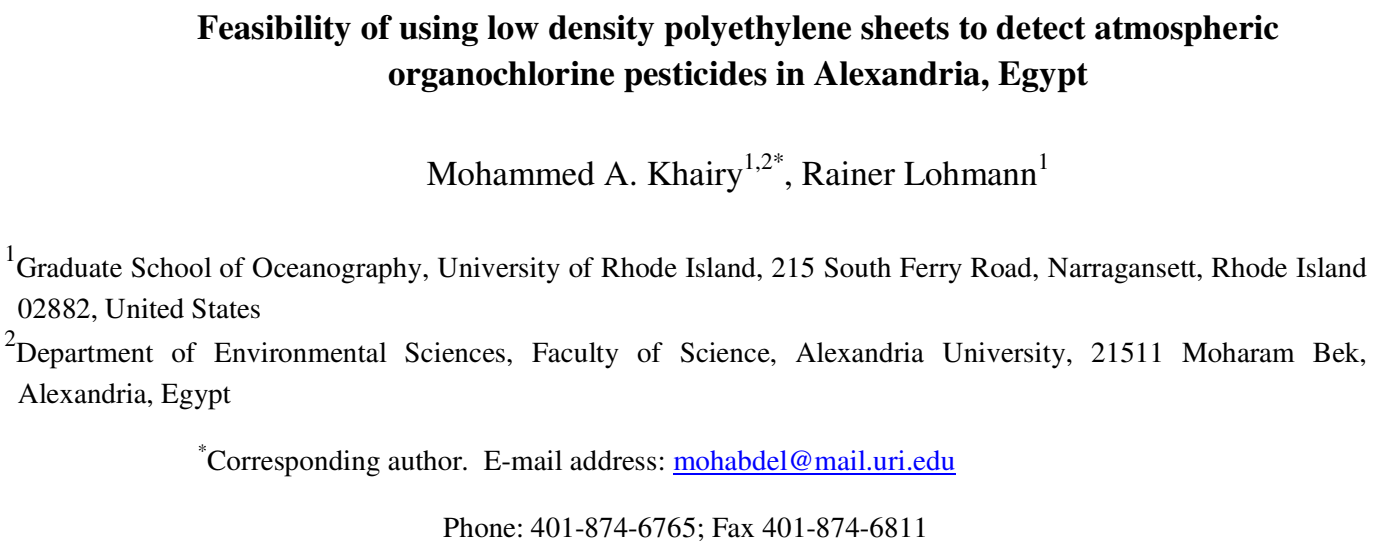

\section{Keywords}

Passive sampling; partitioning constants; Egypt; organochlorine pesticides; Sources

\section{Abstract}

Egypt is a major agricultural country in Africa with a known past of organochlorine pesticides (OCPs) application, yet data on atmospheric levels of OCPs in Egypt is sparse. Low density polyethylene (LDPE) passive samplers were therefore deployed for 3 weeks each at 11 locations in July, 2010 and January, 2011 in Alexandria to screen for gas-phase OCPs. Performance reference compounds were used to investigate the uptake kinetics. Field-derived sampler-air partitioning coefficients $\left(\mathrm{K}_{\mathrm{PE}-\mathrm{A}} \mathrm{s}\right)$ for OCPs were significantly correlated against the compounds' subcooled liquid vapour pressure $\left(\log \mathrm{P}_{\mathrm{L}}\right):\left[\log \mathrm{K}_{\mathrm{PE}-\mathrm{A}}=-0.77 \pm 0.07 * \log \mathrm{P}_{\mathrm{L}}+6.35 \pm 0.13\left(\mathrm{R}^{2}=\right.\right.$ $0.90 ; \mathrm{n}=17 ; \mathrm{SE}=0.19 ; \mathrm{p}<0.001)]$. Estimated and measured OCP concentrations in Alexandria agreed well (factor difference $\leq 2$ ) indicating the feasibility of monitoring OCPs using LDPEs. OCP concentrations ranged from $<\mathrm{LOD}$ to $168 \mathrm{pg} / \mathrm{m}^{3}$. Calculated isomeric ratios indicated recent usage of chlordanes and endosulfans. 
LDPE passive air samplers spiked with PRCs can be used as a practical low cost technique for monitoring gas phase OCPs in Egypt. bioaccumulation (Nakata et al., 2002), toxicity (Lemaire et al., 2004; Souza et al., 2004; Tiido et al., 2005; Murvoll et al., 2006), persistence and long range transportation in the environment (Bailey et al. 2000; Li et al. 2007) causing them to be readily detected even in remote regions and pristine areas such as the Arctic (Hung et al., 2010). Despite being banned for decades in Canada, U.S. and European countries, DDTs, hexachlorocyclohexanes (HCHs), chlordanes and dieldrin continue being detected in the ambient air on regional and continental scales (Van Drooge et al., 2002; Jaward et al., 2004; Shen et al., 2004, 2005; Messing et al., 2013). In some developing countries, however, several OCPs are still in use (Baek et al., 2013).

\section{Introduction}

Organochlorine pesticides (OCPs) are a group of organic pollutants with high

Pesticides were introduced in Egypt in 1952 and about one million metric tons of commercial pesticides were used until 2003 (Mansour, 2004). In addition, illegal pesticides application cannot be ignored due to the poor enforcement of environmental laws. In Egypt, $70 \%$ of the pesticides are applied on cotton crops, while the rest are applied on corn, rice, sugarcane plantations, vegetables and fruits (Mansour, 2004). DDT, lindane and endrin were among the pesticides used to control cotton pests. Three decades ago, the use of DDT in agriculture was officially banned. Following the restriction on DDT, the use of other organochlorine pesticides (e.g., aldrin, dieldrin, chlordane, heptachlor, lindane) was gradually restricted in Egypt (AbouArab et al., 1995; Mansour, 2004).

Despite the fact that Egypt was a signatory of Stockholm Convention held on May, 2002, and the use of OCPs was banned in Egypt, these toxic compounds are still detected in various 
physical and biological environmental compartments in the country (EL Nemr and Abd Allah, 2004; Sallam and Morshedy, 2008; Barakat et al. 2012 a,b; Khairy et al., 2012; Barakat et al.,

59 2013). To our knowledge, limited studies have been carried out to assess the atmospheric levels 60 of OCPs in Egypt, possibly due to the difficulties associated with the conventional active 61 sampling techniques. According to the Stockholm Convention, parties to the Convention should develop a national inventory of POPs. No information exists about the levels, sources and health effects associated with the exposure to atmospheric OCPs in Egypt. Yet frequent measurements of air concentrations in different locations as well as monitoring studies on various levels from local point sources up to the continental scale are a matter of a great importance. Accordingly, cheap techniques that accurately measure atmospheric concentrations of POPs are highly desirable.

Passive air samplers have been proven to be a powerful monitoring technique for POPs, as they are cheaper and require less labour compared to active samplers (Lohmann et al., 2001). Polyurethane foam (PUF) disks (Jaward et al., 2004, 2005; Zhang et al., 2008; Devi et al., 2011) and XAD-2 resin (Choi et al., 2008; Wang et al., 2010; Baek et al., 2013) are the most widely used passive air samplers for monitoring OCPs worldwide. Low density polyethylene (LDPE) has been successfully used as passive air samplers for PAHs (Bartkow et al., 2004; Kennedy et al., 2007; Khairy and Lohmann, 2012).

The purpose of the current study was to investigate the possibility of using LDPE as passive air samplers for OCPs in the atmospheric environment of Alexandria, Egypt. Accordingly, we undertook two major 21-days sampling campaigns of 15 deployments during summer (July, 2010) and winter (January, 2011) across 11 different sites. By deploying samplers 
in different locations and in different seasons, we were able to assess the pollution levels, temporal variations and the possible sources of OCPs in Alexandria using isomeric ratios.

\section{Materials and methods}

\subsection{Site Description}

Alexandria is the second-largest city of Egypt, with a total surface area of $2300 \mathrm{~km}^{2}$ and a population of 4.1 million, extending about $90 \mathrm{~km}$ along the coast of the Mediterranean Sea on the northwestern side of the Nile Delta (Figure SI 1). The city's climate shows Mediterranean characteristics, namely mild, variably rainy winters and hot summers that, at times, can be very humid. More details about the study area can be found in Khairy and Lohmann (2012). The land use map of Alexandria (Figure SI 1) indicated the existence of different land uses including the agriculture, which represented $\sim 27 \%$ of the governorate area and occurred mainly in the south and southeastern parts (Switch, 2011).

\subsection{Preparation and Deployment of LDPEs}

LDPE sheets were cut from commercial sheeting (Carlisle Plastics, Inc., Minneapolis,

MN) with a thickness of $51 \mu \mathrm{m}$, yielding a $10 \times 30 \mathrm{~cm}$ strip of $\sim 1-2 \mathrm{~g}$ each. Samplers were cleaned with DCM and n-hexane and spiked with four performance reference compounds (PRCs) according to the method developed by Booij et al. (2002), namely 2,5-dibromobiphenyl (PBB 9), 2,2',5,5'-tetrabromobiphenyl (PBB 52), 2,2',4,5',6-pentabromobiphenyl (PBB 103) and octachloronaphthalene (see supplementary data, text SI 1 for more details). Once spiked, PEs were strung on stainless steel wires, placed in precleaned aluminum foil packets, numbered, and frozen in plastic bags until the time of deployment. 

locations across Alexandria city (Figure SI 1) each inside two inverted bowls providing protection from direct radiation and rainfall. At each location, LDPEs were deployed for 21 days in July, 2010 (summer season) and January 2011 (winter season) (site and deployment details are given in Table SI 1).

107

\subsection{Active Air Sampling}

Active sampling was performed to validate LDPE as passive air samplers for OCPs (see text SI 1 for more details about the preparation of the active sampling media). Samples were collected using a high volume sampler at the 11 sites in July, 2010 and January 2011 (for meteorological details and sampling volumes, see text SI 2 and Table SI 2). Air was first drawn through a glass fiber filter (GFF) to collect the particulate bound compounds followed by a PUF to retain the vapor phase compounds. Particulate bound data are not presented in the current 115 study.

\subsection{Extraction of LDPEs and PUFs}

LDPEs were cold extracted twice in DCM for 24 hours after spiking with $10 \mu \mathrm{L}$ of a

surrogate standard mixture composed of labeled OCPs $\left({ }^{13} \mathrm{C}_{6}\right.$-hexachlorobenzene and ${ }^{13} \mathrm{C}_{12}-\mathrm{p}, \mathrm{p}$ -

DDT; $5 \mathrm{ng} / \mu \mathrm{L}$ in nonane). Extracts were concentrated to $\sim 1 \mathrm{~mL}$ on a rotary evaporator, solvent exchanged to hexane, and concentrated to $\sim 50 \mu \mathrm{L}$. Ten $\mu \mathrm{L}$ of 2,4,6-tribromobiphenyl ( $5 \mathrm{ng} / \mu \mathrm{L})$, was added as an injection standard before analysis. 
mixture. Extracts were concentrated to a final volume of $\sim 1 \mathrm{~mL}$ using a rotary evaporator (after solvent exchange into hexane) and passed on a glass chromatographic cleanup column packed with silica gel/alumina $(2: 1 \mathrm{wt} / \mathrm{wt})$ in order to remove the interfering compounds (Khairy and Lohmann, 2012). The collected fraction was concentrated to a final volume of $\sim 50 \mu \mathrm{L}$. Finally, 2,4,6-tribromobiphenyl was added as the injection standard before analysis.

\subsection{Instrumental Analysis and Quality Control}

All samples were analyzed for OCPs with an Agilent 6890 Series GC System connected to an Agilent 5973 Network Mass Selective Detector. DDTs ( p,p'-DDE, o,p'-DDD, p,p'-DDD, o,p'-DDT and p,p'-DDT), hexachlorocyclohexanes (HCHs: $\alpha-, \beta-, \gamma$ - and $\delta$-HCH isomers), chlordanes (trans- and cis-chlordane isomers, oxychlordane and trans-nonachlor), heptachlor and its epoxide, aldrin, dieldrin, endosulfans (endosulfan I and II isomers and endosulfan sulfate), hexachlorobenzene $(\mathrm{HCBz})$, endrin, endrin aldehyde, endrin ketone and methoxychlor were investigated. Separation of OCPs was accomplished with a DB-5 MS fused silica capillary column (30 $\mathrm{m} \times 0.25 \mathrm{~mm}$ i.d., $0.25 \mu \mathrm{m}$ film thickness, J\&W Scientific). Abbreviations of OCPs and more details on the instrumental analysis are given in Table (SI 3) and text (SI 3).

Procedural blanks, field blanks, matrix spikes and duplicate samples $(20 \%$ of the total samples) were included with each sample batch, and were carried throughout the entire analytical procedure in a manner identical to the samples. OCPs were completely absent from procedural and field blanks indicating negligible contamination during transport, storage and analysis. Limits of detection (LODs) were determined as the concentration of analytes in a sample giving a peak with a signal-to-noise (S/N) of 3 (Doong et al., 2002). (QA/QC procedures are detailed in text SI 4 and Table SI 3). 


\subsection{Physico-Chemical Properties}

Internally consistent air-water partitioning coefficients $\left(\mathrm{K}_{\mathrm{AW}}\right)$ and octanol-air partitioning coefficients $\left(\mathrm{K}_{\mathrm{OA}}\right)$ were obtained from Schenker et al. (2005). Missing $\mathrm{K}_{\mathrm{OA}}$ values were obtained by correlating available $\mathrm{K}_{\mathrm{OA}}$ values from Schenker et al. (2005) against values obtained from EPI Suite (USEPA, 2011) (Figure SI 2). Missing $\mathrm{K}_{\mathrm{AW}}$ values were calculated according to equation 1 (Reinhard and Drefahl, 1999):

$$
\mathrm{K}_{\mathrm{AW}}=\frac{\mathrm{H}_{\mathrm{c}}}{\mathrm{RT}}
$$

where $H_{c}$ is Henry's law constant (atm.L.mol $\left.{ }^{-1}\right), R$ is the gas constant $(0.08206$ in L.atm/mol.K) and $\mathrm{T}$ is the absolute temperature in Kelvin. $\mathrm{H}_{\mathrm{c}}$ for $\delta-\mathrm{HCH}$ was obtained from Meylan and Howard (2005). Values for oxychlordane, trans-nonachlor, o,p'-DDD, o,p'-DDT and endosulfan sulfate were obtained from SPARC online calculator (V4.5). Values for endrin aldehyde, endrin ketone and methoxychlor were obtained from Mackay et al. (2006). Internally consistent values of the sub-cooled liquid vapor pressure $\left(\mathrm{P}_{\mathrm{L}} / \mathrm{Pa}\right)$ were obtained from Shen and Wania (2005). Missing $\mathrm{P}_{\mathrm{L}}$ values were obtained by correlating values from Shen and Wania (2005) with those obtained from Mackay et al. (2006) (Figure SI 3). $\mathrm{P}_{\mathrm{L}}$ value for trans-nonachlor was obtained from Shoeib and Harner (2002). Values for endrin aldehyde, endosulfan sulfate and endrin ketone were obtained from EPI Suite. Enthalpies of vaporization $\left(\Delta \mathrm{H}_{\text {vap }}\right.$ in $\left.\mathrm{KJ} / \mathrm{mol}\right)$ were obtained from Shoeib and Harner (2002). Missing $\Delta \mathrm{H}_{\text {vap }}$ values were obtained by correlating available values against $\mathrm{P}_{\mathrm{L}}$ (Figure SI 4). Sampler-water partitioning coefficients $\left(\mathrm{K}_{\mathrm{PE}-\mathrm{w}}\right)$ were calculated according to Lohmann (2012). Values of all the physico-chemical parameters are given in Table (SI 4). 


\subsection{Estimated atmospheric concentrations based on LDPE}

PRCs, impregnated in the polyethylene samplers before their deployment, were used to gauge whether OCPs had achieved equilibrium and to adjust for disequilibrium in polyethylene $\left(\mathrm{C}_{\mathrm{LDPE}}\right)$ assuming that uptake and elimination rates are equivalent. (Booij et al., 2002) (Text SI 5). Gaseous atmospheric concentrations $\left(\mathrm{C}_{\mathrm{g}}, \mathrm{ng} / \mathrm{l}\right)$ were calculated from disequilibrium- corrected polyethylene concentrations $\left(\mathrm{C}_{\mathrm{LDPE}}\right)$ as follows:

$$
\mathrm{C}_{\mathrm{g}}=\frac{\mathrm{C}_{\mathrm{LDPE}}}{\left(1-\mathrm{e}^{-\mathrm{k}_{\mathrm{e}}}\right) \cdot \mathrm{K}_{\mathrm{PE}-\mathrm{A}}}
$$

where $\mathrm{C}_{\mathrm{LDPE}}$ is the OCP concentration in the LDPE (ng/kg), $\mathrm{k}_{\mathrm{e}}$ is the loss rate constant of PRCs $\left(\right.$ day $\left.^{-1}\right), \mathrm{t}$ is the deployment period (days) and $\mathrm{K}_{\mathrm{PE}-\mathrm{A}}$ is the sampler-air partitioning coefficient $\left(\mathrm{L} / \mathrm{kg}\right.$ ). To estimate $\mathrm{K}_{\mathrm{PE}-\mathrm{A}}$ values for OCPs, a high volume sampler was left operating for a period of 15 days (5 days per week) at one of the sampling sites (site 2) during the summer season (See text SI 2 for more details). Detected OCP concentrations in the LDPE and PUF samples were used to calculate the $\mathrm{K}_{\mathrm{PE}-\mathrm{A}}$ values according to equation 2. Partition coefficients were adjusted for temperature according to a modified form of Van't Hoff equation (equation 3)

$$
\mathrm{K}_{\text {PE-A }}\left(\mathrm{T}_{2}\right)=\mathrm{K}_{\text {PE-A }}\left(\mathrm{T}_{1}\right) \times \mathrm{e} \frac{-\Delta \mathrm{H}_{\mathrm{vap}}}{\mathrm{R}}\left(\frac{1}{\mathrm{~T}_{2}}-\frac{1}{\mathrm{~T}_{1}}\right)
$$

where $T_{2}$ and $T_{1}$ are the mean temperatures of the deployment and at which the partitioning properties were determined $(\mathrm{K})$

\subsection{Uncertainty associated with $\mathrm{K}_{\mathrm{PE}-\mathrm{A}}$ calculations}

Calculated overall uncertainty combined the uncertainty of predicted partition coefficients, equilibrium adjustment of polyethylene concentrations based on the use of PRCs 
(the fraction equilibration remaining at time of PE sampler collection), and the uncertainty associated with the analysis of the OCPs (See text SI 6 for more details). K undetected OCPs ( $\beta-\mathrm{HCH}, \delta-\mathrm{HCH}$, dieldrin, endosulfan sulfate and methoxychlor) in the field study were predicted from a simple linear relationship with $\mathrm{P}_{\mathrm{L}}$ (see section 3.2, equation 5). Accordingly, we used the same relative uncertainties (RU) in predicted $\mathrm{K}_{\mathrm{PE}^{-} \mathrm{A}} \mathrm{S}$ as given for the $\log \mathrm{P}_{\mathrm{L}}$ by Shen and Wania (2005). Since internally consistent $\mathrm{P}_{\mathrm{L}}$ values did not exist for $\delta-\mathrm{HCH}$, endosulfan sulfate and methoxychlor, they were assigned the highest uncertainty estimate of $\mathrm{P}_{\mathrm{L}}$ $(500 \%)$. The overall uncertainty (Table 1$)$ ranged from $\pm 43.0 \%$ to $\pm 504 \%(0.20-0.80 \log$ units), with higher uncertainty values (303-504\%) for predicted $\mathrm{K}_{\mathrm{PE}-\mathrm{As}}$ compared to the field measured ones (43.0-65.0\%) owing to the greater uncertainty estimates of their $\mathrm{P}_{\mathrm{L}}$.

\section{Table 1}

\section{Results and Discussion}

\subsection{Uptake of OCPs by the LDPE}

The addition of PRCs to the samplers before deployment is useful to infer the exchange rate kinetics, assuming that the elimination rates (of PRCs) and uptake rates (of native compounds) are equivalent (Bartkow et al., 2004). Exchange kinetics were quantified by $\mathrm{k}_{\mathrm{e}}$ (for details, see text SI 5). Four PRCs with different $\log \mathrm{K}_{\mathrm{PE}-\mathrm{A}}$ values were used in this study. The least dissipated PRC in all the investigated samples was pentabromobiphenyl (PBB 103) (Table SI 5). A higher elimination rate was observed for PBB 103 during the winter (30-46 \%) compared to the summer $(25-33 \%)$. The Kruskal-Wallis one way ANOVA statistical test indicated that loss rate constants decrease with increasing the sampler-air partitioning coefficient $\left(\log \mathrm{K}_{\mathrm{PE}-\mathrm{A}}\right)(\mathrm{PBB} 103<\mathrm{OCN}<\mathrm{PBB} 52<\mathrm{PBB} 9)$ in both seasons $\left(\mathrm{H}_{\text {summer }}=39.1, \mathrm{H}_{\text {winter }}=38.6\right.$
Deleted:

\begin{tabular}{|l|} 
Deleted: \\
\hline Deleted: only as that of \\
Deleted: given \\
\hline
\end{tabular}

Deleted:

Deleted: 
at $\alpha=0.05, \mathrm{p}<0.001)$. Moreover, loss rate constants for each of the PRCs were significantly higher in the winter compared to the summer season [Mann-Whitney rank sum test for PBB 9 and PBB 103: $\mathrm{T}=66$ and 73 respectively at $\mathrm{p}<0.001$; $\mathrm{t}$-test for PBB $52(\mathrm{t}=-5.56$ at $\mathrm{p}<0.001)$ and $\mathrm{OCN}(\mathrm{t}=-2.37$ at $\mathrm{p}=0.028)$, which was probably related to the increased wind speed during the winter season (Table SI 1). This indicates that the chemical exchange between the LDPE sampler and the air was limited by the air side boundary layer resistance $\left(\mathrm{k}_{\mathrm{e}} \alpha 1 / \mathrm{K}_{\mathrm{PE}-\mathrm{A}}\right)$ based on the following relation:

$$
\mathrm{k}_{\mathrm{e}}=\frac{\mathrm{k}_{\mathrm{a}} \cdot \mathrm{A}_{\mathrm{s}}}{\mathrm{V}_{\mathrm{s}} \cdot \mathrm{K}_{\mathrm{PE}-\mathrm{A}}}
$$

where $\mathrm{k}_{\mathrm{a}}$ is the mass transfer coefficient through the air side boundary layer and $\mathrm{A}_{\mathrm{s}}$ and $\mathrm{V}_{\mathrm{s}}$ are the sampler surface area and volume respectively.

A correlation between $\log$ transformed $\mathrm{k}_{\mathrm{e}}$ values and $\log \mathrm{K}_{\mathrm{PE}-\mathrm{A}}$ of the PRCs was established to extrapolate $\mathrm{k}_{\mathrm{e}}$ for all the investigated OCPs (Tables SI 6 and 7). At the end of the 21 days deployment period, the average values of $\%$ equilibrium for OCPs (Figure 1) in the samples indicated that OCPs with higher $\mathrm{P}_{\mathrm{L}}$ values were approaching equilibrium $(\mathrm{a}-\mathrm{HCH}, \mathrm{g}-$ $\mathrm{HCH}, \mathrm{HCBz}$ and aldrin) (> $80 \%$ equilibrium), whereas OCPs like DDTs were still far from reaching equilibrium $(<60 \%)$. To gain more information about the accumulation patterns of OCPs, three LDPEs were deployed in each season at one of the sites (site 11), and one was harvested after each week of exposure period (Figure 1). The equilibration of $\alpha$ - and $\gamma-\mathrm{HCH}$, $\mathrm{HCBz}$, aldrin, heptachlor, trans- and cis-chlordane after each week of deployment (week 2 week 1 and week 3 - week 2) started to deviate from the linear uptake after three weeks deployment period in the summer season (Figure 1a), indicating that they were approaching equilibrium. Contrarily, endosulfan I and II, trans-nonachlor, endrin, oxychlordane, p,p'-DDE and p,p'-DDT increased linearly during the sampling period. During the winter season (Figure 
1b), only p,p'-DDD/o,p'-DDT, o,p'-DDD and p,p'-DDT increased linearly during the sampling period, whereas all the other detected OCPs were approaching equilibrium. When the approached \% equilibrium results of OCPs based on the PRCs at site 11 were compared to the variation in the accumulated amounts of OCPs in the LDPE (ng/g PE) with time (Figure SI 6), good agreement was generally observed for the predicted stage of exchange of OCPs between the LDPE sampler and air in both seasons. This implies that PRCs can be used to calibrate sampler/site specific mass transfer behavior, and thus accurately estimate the gaseous concentrations of OCPs (and other POPs) in the atmosphere.

\section{Figure 1}

\subsection{Sampler-air partitioning constants $\left(\mathrm{K}_{\mathrm{PE}-\mathrm{A}}\right)$}

PE-A partitioning constants were calculated directly for 17 OCPs which were detected both in the passive sampler (corrected for non-equilibrium) and the PUFs at site 2 during the field deployments (Table 1). To predict values for the other investigated OCPs, we examined correlation between our measured $\mathrm{K}_{\mathrm{PE}-\mathrm{A}} \mathrm{S}$ and literature $\mathrm{K}_{\mathrm{OA}}$ values, which has been used previously to predict $\mathrm{K}_{\mathrm{PE}-\mathrm{A}} \mathrm{s}$ for PAHs (Bartkow et al., 2004; Khairy and Lohmann, 2012). As shown in Figure (SI 5), a highly significant and strong linear correlation can be observed for PAHs $\left(\mathrm{R}^{2}>0.90, \mathrm{p}<0.001\right)$, whereas for OCPs, the relation explained only $32 \%$ of the total variability in the data.

We observed a significant and strong correlation when $\mathrm{K}_{\mathrm{PE}-\mathrm{A}} \mathrm{S}$ were regressed against $\mathrm{P}_{\mathrm{L}}$ (Pa) $(\mathrm{p}<0.001)($ Figure 2a). The correlation explained $90.0 \%$ of the total variability in the data. The slope was insignificantly different from $-1\left(p<0.001 ; R^{2}=0.90\right)$, implying that $P_{L}$ can be

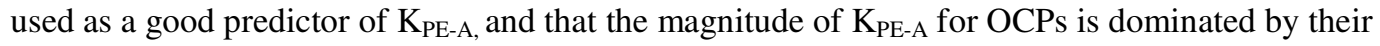
volatilities. The derived $\mathrm{K}_{\mathrm{PE}-\mathrm{A}}$ were calculated from two 3-week field deployments and 
constrained by our ability to safely operate active sampling equipment during the entire field work. Yet the strong correlation with $\mathrm{P}_{\mathrm{L}}$ implies that we were able to derive vales that are well constrained by physico-chemical properties, validating the field-derived data. Accordingly, $\mathrm{K}_{\mathrm{PE}-\mathrm{A}}$ values for the non-quantified OCPs in the passive sampler were predicted (Table 2) based on the derived $\mathrm{P}_{\mathrm{L}}-\mathrm{K}_{\mathrm{PE}-\mathrm{A}}$ relation (equation 5):

$$
\begin{aligned}
& \log \mathrm{K}_{\text {PE-A }}=-0.77 \pm 0.07 \cdot \log \mathrm{P}_{\mathrm{L}}+6.35 \pm 0.13 \\
& \left(\mathrm{n}=17 ; \mathrm{R}^{2}=0.90 ; \mathrm{SE}=0.19\right)
\end{aligned}
$$

\section{Table 2}

\section{Figure 2}

We propose that $\mathrm{K}_{\mathrm{PE}-\mathrm{A}} \mathrm{S}$ for the non-quantified OCPs in the field calibration study can be best predicted from equation (5) despite of the higher degree of uncertainty for endrin, endrin aldehyde, endosulfan sulfate, endrin ketone and methoxychlor (Table 1) as internally consistent physico-chemical properties were missing. For further assessment, calculated $\mathrm{K}_{\mathrm{PE}-\mathrm{A}}$ values were compared with $\mathrm{K}_{\mathrm{PE}-\mathrm{A}}$ values derived using sampler-water partitioning coefficients ( $\left.\mathrm{K}_{\mathrm{PE}-\mathrm{W}}\right)$ and air-water partitioning coefficients $\left(\mathrm{K}_{\mathrm{AW}}\right)$ according to equation 6:

$$
\mathrm{K}_{\text {PE-A }}=\frac{\mathrm{K}_{\text {PE-W }}}{\mathrm{K}_{\mathrm{AW}}}
$$

Calculated (from the field experiment) and predicted $\left(\mathrm{K}_{\mathrm{PE}-\mathrm{W}} / \mathrm{K}_{\mathrm{AW}}\right) \mathrm{K}_{\mathrm{PE}-\mathrm{A}}$ values agreed well within $94 \%$ (factor difference $<0.4 \log$ units) for the majority of the investigated OCPs (Figure 2b). The good agreement observed for most OCPs supports the assumption that our fieldderived $\mathrm{K}_{\mathrm{PE}-\mathrm{A}}$ values are good approximations of their real values, despite the limited deployment period in the field. Contrarily, lower degree of agreement was observed for endrin 
aldehyde, endrin ketone, endosulfan sulfate, trans-nonachlor and oxychlordane (factor difference ranged from $0.60-3.8 \log$ units). One explanation for this lower agreement is related to the degree of uncertainty associated with the partitioning coefficients (uncertainty from $\mathrm{P}_{\mathrm{L}}$ and $\mathrm{K}_{\mathrm{AW}}+$ uncertainty from the $\mathrm{K}_{\mathrm{PE}-\mathrm{A}}$ and $\mathrm{K}_{\mathrm{PE}-\mathrm{w}}$ partitioning coefficients).

\subsection{Spatial distribution and seasonal variations of OCPs}

Estimated atmospheric OCP concentrations in Alexandria are given in Tables (3, SI 8 and SI 9). Based on the average concentrations, the overall trend of OCPs showed the following order: $\mathrm{HCBz}\left(78 \pm 46 \mathrm{pg} / \mathrm{m}^{3}\right)>\mathrm{HCHs}\left(\right.$ sum of $\alpha$ - and $\gamma$ - isomers: $\left.67 \pm 33 \mathrm{pg} / \mathrm{m}^{3}\right)>$ chlordanes (sum of cis- and trans- isomers, oxychlordane, trans-nonachlor, heptachlor and its epoxide: 60.5 $\left.\pm 75 \mathrm{pg} / \mathrm{m}^{3}\right)$, aldrin $\left(59 \pm 48 \mathrm{pg} / \mathrm{m}^{3}\right)>$ endosulfans (sum of endosulfan I and II: $\left.45 \pm 49 \mathrm{pg} / \mathrm{m}^{3}\right)>$ DDTs (sum of o,p'-DDD, o,p'-DDT, p,p'-DDE, p,p'-DDD and p,p'-DDT: $34.5 \pm 43 \mathrm{pg} / \mathrm{m}^{3}$ ) in the summer season, and HCHs $\left(82 \pm 29 \mathrm{pg} / \mathrm{m}^{3}\right)>\operatorname{HCBz}\left(63 \pm 31 \mathrm{pg} / \mathrm{m}^{3}\right)>$ aldrin $(30 \pm 31$ $\left.\mathrm{pg} / \mathrm{m}^{3}\right)>$ chlordanes $\left(19 \pm 15 \mathrm{pg} / \mathrm{m}^{3}\right)>$ endosulfans $\left(15 \pm 19 \mathrm{pg} / \mathrm{m}^{3}\right)>$ DDTs $\left(14 \pm 12 \mathrm{pg} / \mathrm{m}^{3}\right)$ in the winter season. Endrin, endrin aldehyde (EA) and endrin ketone (EK) were only detected at lower concentrations $\left(<\mathrm{LOD}-28 \mathrm{pg} / \mathrm{m}^{3}\right)$ in the summer season and $<\mathrm{LOD}$ in all the winter samples. For most of the investigated OCPs, highest concentrations were always observed at sites 2 and 3 (Figure SI 7). These sites were located in the northeastern part of Alexandria closest to agricultural areas (Figure SI1). In the summer season, concentrations of chlordanes, aldrin, endosulfans, endrin and its metabolites and DDTs were greater at site 2 and site 3, whereas only slight between sample variations were observed for HCHs. A similar trend was observed for aldrin, endosulfans and p,p'-DDE in the winter season. $\mathrm{HCBz}$, in contrast, displayed highest concentrations $\left(23-168 \mathrm{pg} / \mathrm{m}^{3}\right)$ in both seasons at site 2 and site 3 , and other locations 
characterized by high traffic and industrial activities (site 1, 4, 6 and 9). The average HCBz concentration in Alexandria was only slightly higher than its northern hemisphere average concentration $\left(\sim 50 \mathrm{pg} / \mathrm{m}^{3}\right)(\mathrm{J}$ in et al., 2013), but much lower than measured concentrations in China (Liu et al., 2009) and Korea (Li et al., 2007) (Table SI 10). Although HCBz production has ceased in most countries, it is still being generated inadvertently as a by-product and/or impurity in several chemical processes, such as the manufacture of chlorinated solvents, chlorinated aromatics and pesticides. It is also released to the environment by incomplete combustion, and from old dumpsites (Barber et al., 2005).

\section{Table 3}

$\alpha$ - and $\gamma-\mathrm{HCH}$ were the only detected $\underline{\mathrm{HCH}}$ isomers in the atmospheric environment of Alexandria (Figure SI 7). In all the samples, $\alpha-\mathrm{HCH}$ concentrations $\left(<\mathrm{LOD}-98.0 \mathrm{pg} / \mathrm{m}^{3}\right)$ were much higher than the $\gamma-\mathrm{HCH}\left(<\mathrm{LOD}-36.0 \mathrm{pg} / \mathrm{m}^{3}\right)$, especially in the winter season.

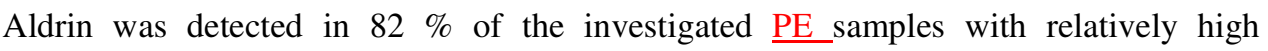
concentrations (<LOD - $147 \mathrm{pg} / \mathrm{m}^{3}$ ) compared to HCHs and HCBz (Figure SI 7). Chlordanes were detected in the majority of the investigated samples. Based on the average concentrations, trans-chlordane showed the highest concentrations in all the samples during both seasons (summer: $19 \mathrm{pg} / \mathrm{m}^{3}$; winter: $9 \mathrm{pg} / \mathrm{m}^{3}$ ) followed by cis-chlordane $\left(8.0 ; 4.0 \mathrm{pg} / \mathrm{m}^{3}\right)$. Oxychlordane, the metabolite of chlordane, was only observed in the summer season with an average concentration of $7.0 \mathrm{pg} / \mathrm{m}^{3}$. Heptachlor epoxide, the metabolite of heptachlor was also observed only in the summer season (higher temperature). The detection of both metabolites only in the summer suggests that they were produced from the photodegradation of parent compounds (Park et al., 2011). 

vectors (Pozo et al., 2011). Concentrations of endosulfans ranged from $9.0-160 \mathrm{pg} / \mathrm{m}^{3}$ and $<$ LOD-65 pg $/ \mathrm{m}^{3}$ in the summer and winter seasons respectively. In all the samples, endosulfan I concentrations were higher than endosulfan II, and endosulfan sulfate was $<$ LOD in all the samples.

p,p'-DDT was widely used in Egypt for agricultural purposes and for the control of disease vectors. Although officially banned in 1988, its was recently detected in sediments of the Egyptian Mediterranean Sea coast (Khairy et al., 2012) and in coastal lakes (Barakat et al.,

2012a, b) because of its long environmental half-life time. In the current study, concentrations of

DDTs were lower than those of HCHs, endosulfans, chlordanes and HCBz (Figure SI 7) ranging from $4-168 \mathrm{ng} / \mathrm{m}^{3}$ and $4-29 \mathrm{pg} / \mathrm{m}^{3}$ in the summer and winter seasons respectively. p, $\mathrm{p}^{-}-\mathrm{DDE}$ was the most frequent and abundant isomer in all the samples comprising 48-96\% of the total concentrations of DDTs in Alexandria. isomers), aldrin and DDTs (p: 0.115-0.861), whereas concentrations of $\gamma-\mathrm{HCH}$ and endosulfans were significantly higher in the summer $(\mathrm{p}=0.009-0.048)$, and $\alpha-\mathrm{HCH}$ was significantly higher in the winter $(\mathrm{p}=0.035)$ (Figure SI 7). but lower than in Asia (Table SI 10). Chlordane concentrations were among the highest when compared to concentrations in other locations worldwide using PUF passive samplers). $\gamma$-HCH and endosulfans on the other hand were lower than concentrations measured in parts of Europe,

\section{Deleted: \\ Deleted: their}

Deleted: DDTs 


\subsection{Source identification of OCPs}

source of the atmospheric OCPs (HCHs), and whether OCPs were released to the atmosphere as a result of fresh application or an aged use (HCHs, chlordanes, endosulfans and DDTs). summer (hot) season, and 3.2-6.7 in the winter (cold) season indicating a possible seasonal revolatilization of old lindane residues. Lower ratio values observed in the summer season could be related to the increased lindane volatilization from soil as a result of elevated atmospheric temperatures

Technical chlordane has been widely used as agriculture pesticide and termiticide in all over the world (Syed et al., 2013). Calculated ratios of trans/cis chlordane in the current study ranged from 1.5-2.9 (Figure SI 8) in both seasons, indicating fresh application of technical chlordane (Hinkcley et al., 1990, Jantunen et al., 2000). According to the UNEP, the use of chlordane is severely restricted and limited to non-agricultural uses in Egypt (UNEP, 2003). ratio is representative of an aged signature, whereas ratios closer to the starting technical mixture suggest recent application. As shown in Figure (SI 8), calculated values in the current study were around the value of the technical mixture (2.3) indicating recent application of endosulfans. application of DDT in the area. 
3.5. Evaluation of the Predictive Ability of the LDPE Samplers

Estimated gaseous OCP concentrations calculated from the LDPE passive samplers corrected for non-equilibrium were compared with the gaseous concentrations actually measured in the atmosphere using the high volume sampler. Results are given in Tables (SI 8 and 9). Although the difference in the sampling periods between the passive (21 days) and active (2-3 days) sampling periods adds uncertainty to the results in Alexandria (Egypt), good agreement was generally observed between estimated and measured OCP concentrations in all the investigated samples (Figure 3 a $\&$ b). During the summer and winter seasons, the difference ranged from a factor of 0.8 to 2.0. Additionally, slopes of both regression lines were not significantly different from one (at $\alpha=0.05, \mathrm{P}<0.001$ ) supporting this good agreement. The significant correlations obtained here suggest that the gas-phase OCP concentrations in Alexandria might not display significant short-term variations during our measurement periods.

This assumption is supported by the observed statistical insignificant difference $(\mathrm{p}=0.128)$ between the weekly measured gas-phase concentrations at site 2 (Figure SI 9) sampled with the conventional active sampling method. Overall, LDPEs have proven to be a powerful tool for predicting atmospheric OCP concentrations in the present study.

\section{Figure 3}

\section{Conclusions}

Our results indicated the feasibility of using LDPE as a practical and low-cost technique

399 for monitoring OCPs in Egypt, and to provide data on the spatial distribution and seasonal 400 variations of OCPs in an urban Egyptian city. Including PRCs enables the use of PE sheets as 
passive air samplers for gas-phase OCPs in general. While our work demonstrated the importance of using PRCs in verifying the equilibrium status of OCPs in PE samplers, a cheaper alternative to circumvent the PRC approach is the use of LDPEs with different surface area-tovolume ratios, as presented by Bartkow et al. (2004). Different passive sampling materials are now popular and their utilization for monitoring organic contaminants in the atmosphere has greatly increased. Future work should concentrate on comparing different passive samplers as a function of deployment times, temperature and wind speed so that data derived from different studies are broadly comparable, and the levels of confidence around the data are known.

Estimated concentrations of atmospheric OCPs in Alexandria, Egypt were within the global range as measured in the global atmospheric passive sampling network (GAPS). Yet the detection of OCPs in the Egyptian environment, especially those with fresh sources as indicated by the isomeric ratios questions the efficacy of the official ban of most of the investigated OCPs in Egypt from decades. This could encourage decision makers in Egypt (and beyond) to utilize this cost-effective sampling tool for developing an extensive local air sampling network. With the use of passive samplers, data can be acquired about sources and concentrations of organic pollutants and to develop effective control measures.

\section{Supplementary information}

Supplementary data associated with this article can be found in the online version.

\section{Acknowledgment}

Authors would like to thank Mr. Dave Adelman (GSO, URI) for his effort in PE preparation. Dr. Mohammed Khairy acknowledges the Fulbright Foundation for offering him the opportunity to carry this research in USA. Dr. Rainer Lohmann acknowledges funding from EPA's Great Lakes Restoration Initiative Award GLAS \# 00E00597-0 supporting passive sampler research at URI. 


\section{References}

Abou-Arab, A.A.K., Gomaa, M.N.E., Badawy,A., Naguib, K., 1995. Distribution of organochlorine pesticides in the Egyptian aquatic ecosystem. Food Chemistry 54, 141-146 .

Baek, S.Y., Jurng, J., Chang, Y.S., 2013. Spatial distribution of polychlorinated biphenyls, organochlorine pesticides, and dechlorane plus in Northeast Asia. Atmospheric Environment 64, 40-46.

Bailey, R., Barrie, L.A., Halsall, C.J., Fellin, P., Muir, D.C.G., 2000. Atmospheric organochlorine pesticides in the western Canadian Arctic: Evidence of transpacific transport. Journal of Geophysical Research: Atmospheres 105, 11805-11811.

Barakat, A.O., Mostafa, A., Wade, T.L., Sweet, S.T., El Sayed, N.B., 2012a. Assessment of persistent organochlorine pollutants in sediments from Lake Manzala, Egypt. Marine Pollution Bulletin 64, 1713-1720.

Barakat, A.O., Mostafa, A., Wade, T.L., Sweet, S.T., El Sayed, N.B., 2012b. Spatial distribution and temporal trends of persistent organochlorine pollutants in sediments from Lake Maryut, Alexandria, Egypt. Marine Pollution Bulletin 64, 395-404.

Barakat, A.O., Khairy, M., Aukaily, I., 2013. Persistent organochlorine pesticide and PCB residues in surface sediments of Lake Qarun, a protected area of Egypt. Chemosphere 90, 24672476.

Barber, J.L., Sweetman, A.J., van Wijk, D., Jones, K.C., 2005. Hexachlorobenzene in the global environment: Emissions, levels, distribution, trends and processes. Science of the Total Environment 349, 1-44.

Bartkow, M.E., Hawker, D.W., Kennedy, K.E., Muller, J.F., 2004. Characterizing uptake kinetics of PAHs from the air using polyethylene-based passive air samplers of multiple surface 
area-to-volume ratios. Environmental Science and Technology 38, 2701-2706.

Booij, K., Smedes, F., van Weerlee, E.M., 2002. Spiking of performance reference compounds in low density polyethylene and silicone passive water samplers. Chemosphere 46, 1157-1161.

Choi, S.D., Baek, S.Y., Chang, Y.S., Wania, F., Ikonomou, M.G., Yoon, Y.J., Park, B.K.. Hong, S., 2008. Passive air sampling of polychlorinated biphenyls and organochlorine pesticides at the Korean Arctic and Antarctic research stations: Implications for long-range transport and local pollution. Environmental Science and Technology 42, 7125-7131.

Daly, G.L., Lei, Y.D., Teixeira, C., Muir, D.C.G., Castillo, L.E., Jantunen, L.M.M., Wania, F., 2007. Organochlorine pesticides in the soils and atmosphere of Costa Rica. Environmental Science and Technology 41, 1124-1130.

Devi, N.L., Qi, S., Chakraborty, P., Zhang, G., Yadav, I.C., 2011 Passive air sampling of organochlorine pesticides in a northeastern state of India, Manipur. Journal of Environmental Sciences 23, 808-815.

Doong, R.A., Sun, Y.C., Liao, P.L., Peng, C.K.,Wu, S.C., 2002. Distribution and fate of organochlorine pesticide residues in sediments from the selected rivers in Taiwan. Chemosphere $48,237-246$.

El Nemr, A., Abd-Allah, A.M.A., 2004. Organochlorine contamination in some marketable fish in Egypt. Chemosphere 54, 1401-1406.

EPA, U.S. EPI Suite v4.10. 2011.

Hinckley, D.A., Bidleman, T.F., Foreman, W.T., Tuschall, J.R., 1990 Determination of vapor pressures for nonpolar and semipolar organic compounds from gas chromatograhic retention data. Journal of Chemical Engineering Data 35, 232-237.

Hung, H., Kallenborn, R., Breivik, K., Su, Y., Brorstom-Lunden, E., Olafsdottir, K., Thorlacius, 
J.M., Leppanen, S., Bossi, R., Skov, H., Mano, S., Patton, G.W., Stern, G., Sverko, E., Fellin, P., 2010. Atmospheric monitoring of organic pollutants in the Arctic under the Arctic Monitoring and Assessment Programme (AMAP): 1993-2006. Science of the Total Environment 408, 28542873.

Jantunen, L.M.M., Bidleman, T.F., Harner, T., Parkhurst, W.J., 2000. Toxaphene, chlordane, and other organochlorine pesticides in Alabama air. Environmental Science and Technology 34, $5097-5105$.

Jaward, F.M., Farrar, N.J., Harner, T., Sweetman, A.J., Jones, K.C., 2004 Passive Air Sampling of PCBs, PBDEs, and Organochlorine Pesticides Across Europe. Environmental Science and Technology 38, 34-41.

Jaward, F.M., Zhang, G., Nam, J.J., Sweetman, A.J., Obbard, J.P., Kobara, Y., Jones, K.C., 2005. Passive air sampling of polychlorinated biphenyls, organochlorine compounds, and polybrominated diphenyl ethers across Asia. Environmental Science and Technology 39, 86388645.

Jin, G.Z., Kim, S.M., Lee, S.Y., Park, J.S., Kim, D.H., Lee, M.J., Sim, K.T., Kang, H.G., Kim, I.G., Shin, S.K., Seok, K.S., Hwang, S.R., 2013 Levels and potential sources of atmospheric organochlorine pesticides at Korea background sites. Atmospheric Environment 68, 333-342.

Kennedy, K.E., Hawker, D.W., Muller, J.F., Bartkow, M.E., Truss, R.W., 2007 A field comparison of ethylene vinyl acetate and low-density polyethylene thin films for equilibrium phase passive air sampling of polycyclic aromatic hydrocarbons. Atmospheric Environment 41, $5778-5787$.

Khairy, M.A., Lohmann, R., 2012. Field Validation of polyethylene passive air samplers for parent and alkylated PAHs in Alexandria, Egypt. Environmental Science and Technology 46, 
3990-3998.

Khairy, M.A., Kolb, M., Mostafa, A., El-Fiky, A., Bahadir, M., 2012 Risk posed by chlorinated organic compounds in Abu Qir Bay, East Alexandria, Egypt. Environmental Science and Pollution Research 19, 794-811.

Lemaire, G.R., Terouanne, B.A., Mauvais, P., Michel, S., Rahmani, R., 2004. Effect of organochlorine pesticides on human androgen receptor activation in vitro. Toxicology and Applied Pharmacology 196, 235-246.

Li, J., Zhang, G., Guo, L., Xu, W., Li, X., Lee, C.S.L., Ding, A., Wang, T., 2007. Organochlorine pesticides in the atmosphere of Guangzhou and Hong Kong: Regional sources and long-range atmospheric transport. Atmospheric Environment 41, 3889-3903.

Liu, X., Zhang, G., Li, J., Yu, L.L., Xu, Y., Li, X.D., Kobara, Y., Jones, K.C., 2009. Seasonal patterns and current sources of DDTs, chlordanes, hexachlorobenzene, and endosulfan in the atmosphere of 37 Chinese Cities. Environmental Science and Technology 43, 1316-1321.

Lohmann, R., 2012 Critical review of low-density polyethylene's partitioning and diffusion coefficients for trace organic contaminants and implications for its use as a passive sampler. Environmental Science and Technology 46, 606-618.

Lohmann, R., Corrigan, B.P., Howsam, M., Jones, K.C., Ockenden, W.A., 2001. Further developments in the use of semipermeable membrane devices (SPMDs) as passive air samplers for persistent organic pollutants: field application in a spatial survey of PCDD/Fs and PAHs. Environmental Science and Technology 35, 2576-2582.

Mackay, D.S., Wan, W.Y., Ma, K.C., Lee, S.C., 2006 Handbook of physical-chemical properties and environmental fate of organic chemicals. Second edition ed.; CRC Press, Taylor \& Francis Group, : Florida, USA, 2006. 
Mansour, S.A., 2004. Pesticide exposure-Egyptian scene, Toxicology 198, 91-115.

Messing, P., Farenhorst, A., Waite, D., Sproull, J., 2013. Influence of usage and chemicalphysical properties on the atmospheric transport and deposition of pesticides to agricultural regions of Manitoba, Canada. Chemosphere 90, 1997-2003.

Meylan, W.M., Howard, P.H., 2006. Estimating octanol-air partition coefficients with octanolwater partition coefficients and Henry's law constants. Chemosphere 61, 640-644.

Murvoll, K.M., Skaare, J.U., Moe, B., Anderssen, E., Jenssen, B.M., 2006. Spatial trends and associated biological responses of organochlorines and brominated flame retardants in hatchlings of North Atlantic kittiwakes (Rissa tridactyla). Environmental Toxicology and Chemistry 25, $1648-1656$.

Nakata, H., Kawazoe, M., Arizono, K., Abe, S., Kitano, T., Shimada, H., Li, W., Ding, X., 2002. Organochlorine pesticides and polychlorinated biphenyl residues in foodstuffs and human tissues from China: Status of contamination, historical trend, and human dietary exposure. Archives of Environmental Contamination and Toxicology 43, 0473-0480.

Park, J.S., Shin, S.K., Kim, W., Kim B.H., 2011. Residual levels and identify possible sources of organochlorine pesticides in Korea atmosphere. Atmospheric Environment 45, 7496-7502.

Pozo, K., Harner, T., Lee, S.C., Sinha, R.K., Sengupta, B., Loewen, M., Geethalakshmi, V., Kannan, K., Volpi, V., 2011. Assessing seasonal and spatial trends of persistent organic pollutants (POPs) in Indian agricultural regions using PUF disk passive air samplers. Environmental Pollution 159, 646-653.

Reinhard, M., Drefahl, A., 1999. Handbook for estimating physicochemical properties for organic compounds; John Wiley \& Sons, Inc.: New York, USA.

Sallam, K.I., Morshedy, A.E.M.A., 2008. Organochlorine pesticide residues in camel, cattle and 
sheep carcasses slaughtered in Sharkia Province, Egypt. Food Chemistry 108, 154-164.

Schenker, U., MacLeod, M., Scheringer, M., Hungerbuhler, K., 2005. Improving data quality for environmental fate models: A least-squares adjustment procedure for harmonizing

546 physicochemical properties of organic compounds. E Environmental Science and Technology $547 \quad 39,8434-8441$.

548 Shen, L., Wania, F., Lei, Y.D., Teixeira, C., Muir, D.C.G., Bidleman, T.F., 2004.

549 Hexachlorocyclohexanes in the North American Atmosphere. Environmental Science and

550 Technology 38, 965-975.

551 Shen, L., Wania, F., 2005. Compilation, evaluation, and selection of physical-chemical property 552 data for organochlorine pesticides. Journal of Chemical and Engineering Data 50, 742-768.

553 Shen, L., Wania, F., Lei, Y.D., Teixeira, C., Muir, D.C.G., Bidleman, T.F., 2005. Atmospheric 554 Distribution and Long-Range Transport Behavior of Organochlorine Pesticides in North 555 America. Environmental Science and Technology 39, 409-420.

556 Shoeib, M., Harner, T., 2002. Using measured octanol-air partition coefficients to explain 557 environmental partitioning of organochlorine pesticides. Environmental Toxicology and 558 Chemistry 21, 984-990.

559 Souza, M.S., de Potas, G.M., de D'Angelo, A.M.P., 2004. Organophosphorous and 560 organochlorine pesticides affect human placental phosphoinositides metabolism and PI-4 kinase 561 activity. Journal of Biochemistry and Molecular Toxicology 18, 30-36.

562 Switch. Alexandria 2030:- Integrated urban water management (IUWM) strategic plan. Switch 563 Central Management Unit, UNESCO-IHE, The Netherlands, 2011;

564 http://switchurbanwater.lboro.ac.uk/outputs/pdfs/W1-

565 1_CALE_RPT_D1.1.6_Strategic_Planning_Process_-_Alexandria.pdf. 
566 Syed, L.H., Malik, R.N., Liu, D., Xu, Y., Wang, Y., Li, J., Zhang, G., Jones, K.C., 2013.

567 Organochlorine pesticides in air and soil and estimated air-soil exchange in Punjab, Pakistan.

568 Science of the Total Environment 444, 491-497.

569 Tiido, T., Rignell-Hydbom, A., Jonsson, B., Giwercman, Y.L., Rylander, L., Hagmar, L., 570 Giwercman, A., 2005. Exposure to persistent organochlorine pollutants associates with human 571 sperm Y:X chromosome ratio. Human Reproduction 20, 1903-1909.

572 United Nation Environmental Program (UNEP), 2003. Draft technical guidelines on the 573 environmentally sound management of persistent organic pollutants as wastes, Geneva,.

574 Van Drooge, B.L., Grimalt, J.O., Torres Garcla, C.J.T., Cuevas, E., 2002. 'Semivolatile 575 Organochlorine Compounds in the Free Troposphere of the Northeastern Atlantic. 576 Environmental Science and Technology 36, 1155-1161.

577 Wang, X.P., Gong, P., Yao, T.D., Jones, K.C., 2010. Passive air sampling of organochlorine 578 pesticides, polychlorinated biphenyls, and polybrominated diphenyl ethers across the Tibetan 579 Plateau. Environmental Science and Technology 44, 2988-2993.

580 Zhang, G., Chakraborty, P., Li, J., Sampathkumar, P., Balasubramanian, T., Kathiresan, K., 581 Takahashi, S., Subramanian, A., Tanabe, S., Jones, K.C., 2008. Passive atmospheric sampling of 582 organochlorine pesticides, polychlorinated biphenyls, and polybrominated diphenyl ethers in 583 urban, rural, and wetland sites along the coastal length of India. Environmental Science and 584 Technology 42, 8218-8223. 